(December 14, 1940)

BUIIDING REGULAT ION:

Publications issued by the National Bureau of Standards

\title{
GENTRAI INPORNATION
}

In the following list, where the price is stated, the publication can be purchased from the superintendent of Documents, Government Printing Office, Washington, D. C. The prices quoted are for delivery to addresses in the United States and'its territories and possessions and in certain foreign countries which extend the franking privilege. In the case of all other countries, one-third the cost of the publication should be added to cover postage. Remittances should be made either by coupons lobtainable from the Superintendent of Docunents in sets of 20 for $\$$. 1.00 and good until used), or by check or money order payable to the "Superintendent of Documents, Government Printing Office" and sent to him with order.

Publications marked "OP" are out of print, but, in general, may be consulted at technical libraries.

Series letters with serial numbers are used to designate Bureau publications:

$$
\begin{aligned}
& \mathrm{BH}=\text { "Building and Housing" publication. } \\
& M=\text { "Miscellaneous Publication". } \\
& \text { BMS = "Building Naterials and Structures" publication. }
\end{aligned}
$$

An order blank will be found at the end of this list.

\section{BUIIDIIG REGUIATION}

Series Price

Proparation and revision of building codes. G. T. Thompson.

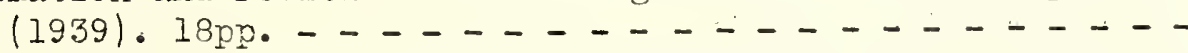

Presents information for the use of local cormittees. charged with the responsibility of preparing or revising building codes. This is drawn from material accumulated at the National Bureau of Standards over a:period of years in connection with development of recommended building code requirements. Covers the influence of the building code on 
the community; the basic principles involved; deficiencies evident in existing codes; methods of arrangement, numbering, and presentation; and the use of national standards. Gives reference to sources of technical information and to articles by various authorities on the subject. Also gives extracts from local codes, to illustrate various ways of dealing with major problems.

Recommended mininur requirements for small dwelling construction.

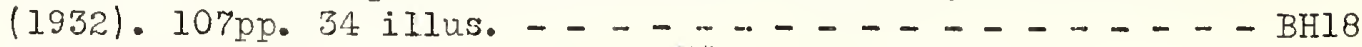
(Supersedes BHl)

Presents recommended kuilding code requirements for oneand two-family dwellings not over three stories in height, covering all materials and methods of construction. Appendix contains valuable discussion of good practice in construction of gmall dwellings.

Recominended hinimu requirements for plumbing (including Supplement, Progress Ravision, May, 1931). (1932). 283pp.

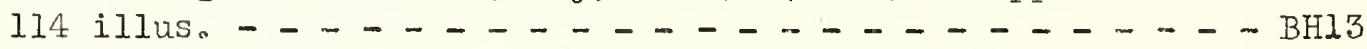
(Supersejas BH2)

Presents recommended plumbing code requirements for installations in all types of buildings; together with a statement of the fundamental principles governing plumbing regulation; a discussion of licensing and regulation of plumbers; a description of extensive experiments on which recommended requirements are based; notes on various special features of plumbing installations. (For later treatment of the subject in somewhat different form, see BMSE6.)

Plumbing manual: Report of Subcommittee on Plumbing, Certral Housing Committee on Research, Design, and Construction. (1940). 70yp. 24 illus. $\ldots \ldots-\ldots$

Presents recommendations regarding pipe sizes, precauBHS 66 tions against pollution of water supply, types of venting, and other matters usually covered in plumbing codes; and gives information useful in applying the recommendations. Prepared by a committee composed of representatives of Federal agencies after consideration of extensive experimental work and other information available since BHl3 (see above) was issued. Useful as a reference in connection with development of local plumbing codes.

Recommended minimum requirements for masonry vall construction. (1924). 57pp. 4 ililus. $-\ldots+\ldots$

Presents recomended code requirements for the height, thickness, materials, and workmanship of masonry walls for all purposes; together with information on good practice in masonry construction and the factors which affect strength of masonry. (Including Supplement to above griving modifications in brick masonry stresses.) 
Minimum live loads allowable for use in design of buildings. (1924). 38p. . . . . . . . . . . . . . .

Presents recommended minimun live loads to be assumed as the basis for building design; together with much information on the floor loads characteristic of different occupancies or resulting from storage of different commodities. Report includes material on wind pressures, impact allowances, and administration of live load requirements in building codes.

Recommended minimum requirements for fire resistance in buildings. (1930). 58pp. 4 illus. _ . . . . . . . . . . - BH14

Presents recormended building code requirements for height and undivided area of buildings from the standpoint of fire resistance; divides buildings into types according to materials entering into their construction; gives minimum protection desirable for structural members; discusses fundamentals of fire protection and gives references to test data and other useful information.

Design and construction of building exits. (1935). $76 \mathrm{pp}$. 19 illus. . . . . . . . . . . . . . . . . .

Presents results of a study of current practice in exit design and of observations on the flow of persons down stairways and through doorways; discusses types of exit requirements in current use; contains an appendix in which are given recommendations for consideration in revising building codes.

The following publications are now out of print but are available for reference at technical librories.

Recommended practice for arrangenent of building codes. (1925) $29 \mathrm{pp} . \ldots \ldots \ldots$. . . . . . . . . . . - - B B

Gives detailed outline for arrangement of building code provisions; together with discussion of methods of drafting, revising, and publishing such ordinances; and a list of the available sources of information on building refulations, standards for materials, and methods of construction.

Recommended building code requirements for working stresses in building materials. (1926). 53pp. 4 illus. - . - - -

Presents recommended working stress requirements for reinforced concrote, cast iron, stecl, and timber; together with a discussion of inprovements in materials, design, and methods of construction. 

Detach and mail to

Superintendent of Discuments, Government Printing Orice, Washington, D. C.

Date

Enclosed is the following publications:

Publication

Price

(money onder, Tew York draft, or coin) for 
